\title{
Pengaruh Perceived Usefulness dan Perceived Ease of Use Terhadap Attitude Toward Using E-Wallet pada Mahasiswa Selama Pandemi COVID-19
}

\author{
Ryan Ariesco Wijaya1, Dwi Andriyanti Agustin², Janviera Adriana Nugrahani ${ }^{3}$ \\ 123 Manajemen Inovasi Universitas Ma Chung, Villa Puncak Tidar Blok N No.1, Malang, Indonesia 65151 \\ Correspondence: Dwi Andriyanti Agustin(132020008@student.machung.ac.id) \\ Received: 090821 - Revised: 100821 - Accepted: 160821 - Published: 280921
}

\begin{abstract}
Abstrak. Penelitian ini dilatarbelakangi oleh dampak pandemi COVID-19 yang meningkatkan transaksi di berbagai $e$-commerce. Metode pembayaran di berbagai $e$-commerce platform sudah jarang menggunakan uang tunai karena digantikan dengan menggunakan $e$-wallet untuk mengurangi kontak fisik. Penelitian ini menggunakan Technology Acceptance Model (TAM) sebagai landasan teori. Penelitian ini menguji pengaruh perceived usefulness dan perceived ease of use terhadap attitude toward using e-wallet pada mahasiswa selama pandemi COVID-19. Jenis penelitian yang digunakan adalah penelitian kausal. Populasi yang akan digunakan dalam penelitian ini adalah seluruh mahasiswa Universitas Ma Chung. Sedangkan untuk sampel yang digunakan adalah mahasiswa S1 Program Studi Manajemen dan mahasiswa S2 Program Magister Manajemen Inovasi Universitas Ma Chung dengan jumlah sebanyak 62 responden. Variabel dalam penelitian ini diukur dengan menggunakan skala Likert. Penelitian ini menggunakan uji validitas, uji reliabilitas, uji asumsi klasik, dan uji hipotesis. Berdasarkan hasil penelitian, perceived usefulness tidak berpengaruh terhadap attitude toward using mahasiswa dalam menggunakan $e$-wallet. Selain itu, perceived ease of use berpengaruh positif terhadap attitude toward using mahasiswa dalam menggunakan $e$-wallet.
\end{abstract}

Kata kunci: e-wallet, perceived usefulness, perceived ease of use, attitude toward using

Abstract. This research is motivated by the impact of the COVID-19 pandemic which increased transactions in various e-commerce. Payment methods on various e-commerce platforms have rarely used cash because they use e-wallet to reduce physical contact. This study uses the Technology Acceptance Model (TAM) as the theoretical basis. This study examines the effect of perceived usefulness and perceived ease of use on students' attitudes towards using e-wallet during the COVID-19 pandemic. The type of research used is causal research. The population that used in this research was all students of Ma Chung University. Meanwhile, the samples used were students of the Bachelor of Management Studies Program and students of the Master's Degree Program in Innovation Management at Ma Chung University with a total of 62 respondents. The variables in this study were measured using a Likert scale. This research uses validity test, reliability test, classical assumption test, and hypothesis test. Based on the results of the study, perceived usefulness has no effect on student's attitudes toward using e-wallet. In addition, the perception ease of use has a positive effect on student's attitudes toward using e-wallet.

Keyword: e-wallet, perceived usefulness, perceived ease of use, attitude toward using

Citation Format: Wijaya, R.A., Agustin, D.A., Nugrahani, J.A,. (2020). Pengaruh Perceived Usefulness dan Perceived Ease of Use Terhadap Attitude Toward Using E-Wallet pada Mahasiswa Selama Pandemi COVID-19. Prosiding Seminar Nasional Abdimas Ma Chung (SENAM), 2020, 146-158 


\section{PENDAHULUAN}

\section{Latar Belakang}

Di akhir tahun 2019, seluruh dunia merasakan dampak akibat pandemi COVID-19 (Coronavirus disease 2019) yang merupakan jenis penyakit baru yang disebabkan oleh virus SARS-CoV-2. Hampir seluruh sektor terdampak termasuk sektor ekonomi karena salah satunya pembatasan aktivitas masyarakat. Di sisi lain pandemi Covid-19 mempercepat pergeseran menuju dunia yang lebih digital dan memicu perubahan perilaku belanja online. Secara perlahan dampak pandemi Covid-19 meningkatkan transaksi di berbagai $e$-commerce. Metode pembayaran di berbagai platform e-commerce sudah jarang menggunakan uang tunai karena digantikan dengan menggunakan $e$-wallet untuk mengurangi kontak fisik. Berdasarkan survei oleh United Nations Conference on Trade and Development (UNCTAD) terhadap sekitar 3.700 konsumen di sembilan negara maju dan berkembang yakni Brasil, China, Jerman, Italia, Korea Selatan, Federasi Rusia, Afrika Selatan, Swiss dan Turki, disampaikan bahwa lebih dari 50\% responden berbelanja online dan lebih mengandalkan internet. Survei menunjukkan bahwa konsumen di negara berkembang telah melakukan peralihan terbesar ke belanja online (Lestari, 2020).

Sejarah munculnya $e$-wallet diawali dengan lahirnya $e$-money terlebih dahulu. $E$ money digagas pada tahun 1960 oleh IBM dan American Airlines dengan menciptakan SABRE (Semi-Automatic Business Research Environment) untuk melakukan reservasi penerbangan dengan sistem kredit. Pada tahun 1997, perusahaan Coca Cola menawarkan pembelian di vending machine dengan menggunakan mobile payments. Semenjak itu, banyak produk e-money dikembangkan dan diperkenalkan ke masyarakat (Pendidikan2, 2021). E-money kemudian menjadi ide bagi beberapa perusahaan start up untuk membangun bisnis di bidang fintech (financial technology) yang kemudian melahirkan $e$-wallet.

Data nominal omzet rata-rata per bulan transaksi $e$-wallet berdasarkan survei konsumen secara online yang dilakukan oleh Snapcart selama kuartal I di tahun 2021 disampaikan bahwa $e$-wallet dengan brand ShopeePay menguasai 38\% dari total transaksi $e$ wallet, diikuti Ovo (19\%), Gopay (19\%), Dana (17\%), dan LinkAja (7\%). Dari survei tersebut juga menyatakan bahwa brand $e$-wallet ShopeePay yang paling diingat pelanggan, paling sering digunakan, dan paling disukai konsumen Indonesia (Prasetyo, 2021). Sedangkan untuk nominal transaksi uang elektronik melalui $e$-wallet yang ada di Indonesia sampai dengan tahun 2020 mencapai Rp 204.909.170.000 (www.bi.go.id, 2021). 
Berdasarkan survei iPrice yang bekerja sama dengan Jakpat ditemukan bahwa 26\% masyarakat telah menggunakan $e$-wallet untuk berbelanja secara online. Penelusuran lebih dalam dinyatakan bahwa konsumen lebih sering menggunakan $e$-wallet ketimbang $e$-money. Hal ini tercermin dari hasil riset Katadata Insight Center (KIC) bahwa 11,1\% responden menggunakan aplikasi Dana setiap hari. Dana adalah salah satu jenis $e$-wallet yang beredar di masyarakat (Ridhoi, 2020).

Kemudahan penggunaan $e$-wallet juga dirasakan oleh kelompok konsumen dari kalangan mahasiswa. Pengertian mahasiswa menurut UU no 12 tahun 2012 tentang pendidikan tinggi adalah peserta didik pada jenjang Pendidikan Tinggi yang berbentuk akademi, institusi maupun universitas. Adapun jenjang pendidikan tinggi adalah dari strata 1 (satu) hingga strata 3 (tiga). Usia mahasiswa strata 1 (satu) berkisar antara 18-24 tahun, merupakan usai antara remaja dan dewasa muda. Usia remaja adalah usia 12 sampai dengan 20 tahun dan dewasa muda adalah usia antara 20-40 tahun (Mulyadi, 2010). Usia remaja memiliki gaya hidup yang berbeda dan menentukan pola perilaku, nilai, dan sifat yang paling sesuai bagi dirinya (Saputro, 2018). Penelitian ini memposisikan mahasiswa sebagai konsumen e-wallet. Pengertian konsumen berdasarkan Undang-Undang RI No.8 Tahun 1999 pasal (1) ayat (2) tentang Perlindungan Konsumen didefinisikan sebagai individu yang memakai barang atau jasa yang tersedia dalam masyarakat, baik untuk kepentingan diri sendiri, keluarga, orang lain, maupun makhluk yang lain dan tidak untuk diperdagangkan.

Penelitian ini menggunakan Technology Acceptance Model (TAM). TAM merupakan model pengembangan Theory of Reasoned Action (TRA) dengan menambah dua konstruk utama ke dalam model TRA, yaitu persepsi manfaat (perceived usefulness) dan persepsi kemudahan (perceived ease of use). Model TAM jauh lebih luas dibandingkan dengan model TRA. TAM menggunakan pendekatan teori perilaku dan banyak digunakan untuk mengkaji proses adopsi teknologi informasi. Teori ini menjadi dasar untuk mengetahui pengaruh faktor eksternal terhadap kepercayaan, sikap, dan tujuan dari penggunanya. Bisa dikatakan bahwa TAM merupakan suatu model analisis untuk mengetahui perilaku pengguna akan penerimaan teknologi. Studi empiris terkait TAM yang dilakukan oleh (Rahmatika \& Fajar, 2019) menunjukkan bahwa, persepsi manfaat, persepsi kemudahan penggunaan, sikap, norma subjektif, dan persepsi kontrol perilaku mempengaruhi minat responden untuk menggunakan e-money.

Studi empiris yang dilakukan pada mahasiswa terkait dengan penggunaan $e$-wallet dalam penelitian (Nawawi, 2020) menyatakan bahwa alasan mendasar mahasiswa menggunakan $e$-wallet sebagai metode pembayaran, yakni karena banyaknya promo yang 
ditawarkan, serta pengguna mendapatkan kenyamanan dalam bertransaksi, juga mudah dalam pengoperasiannya. Dalam menggunakan $e$-wallet, mahasiswa tidak saja merasakan kenyamanan dalam berbelanja, tapi juga kenyamanan dalam pembayaran karena dapat dilakukan dimana saja selama pengguna terhubung dengan internet (Nawawi, 2020). Melalui penelitian ini penulis ingin menganalisis faktor-faktor yang mempengaruhi attitude toward using mahasiswa dalam menggunakan $e$-wallet pada masa pandemi Covid-19.

\section{Tinjauan Pustaka}

Pengertian Dompet Elektronik (Electronic Wallet- $e$-wallet) menurut Peraturan Bank Indonesia No. 18/40/PBI/2016 tentang Penyelenggaraan pemrosesan transaksi pembayaran pada Pasal 1 ayat 7 adalah layanan elektronik untuk menyimpan data instrumen pembayaran antara lain alat pembayaran dengan menggunakan kartu dan/atau uang elektronik, yang dapat juga menampung dana, untuk melakukan pembayaran.

Technology Acceptance Model (TAM) adalah model penelitian yang dilakukan untuk menganalisis faktor-faktor yang mempengaruhi penerimaan (acceptance) penggunaan teknologi informasi. Fred D. Davis memperkenalkan TAM pertama kali pada tahun 1986, dibuat khusus untuk memodelkan efek penerimaan (acceptance) yang dirasakan pengguna terhadap sebuah teknologi informasi. Menurut (Davis, Marangunic, \& Granic, 2021), tujuan utama TAM adalah memberikan acuan untuk menganalisa pengaruh eksternal berupa faktor keyakinan (trust), intention, dan tujuan pengguna. Ada dua faktor yang dominan dalam TAM yang mempengaruhi penerimaan (acceptance) teknologi informasi yaitu yang pertama, persepsi pengguna tentang manfaat (perceived usefulness) yang dirasakan pengguna saat menggunakan teknologi tersebut, dan kedua, persepsi pengguna tentang kemudahan (perceived ease of use) penggunaan teknologi informasi.

Perceived usefulness menjelaskan bahwa dengan sikap penerimaan pengguna terhadap sistem teknologi informasi, para pengguna diharapkan dapat lebih meningkatkan kinerjanya dalam melakukan pekerjaan. Jika pengguna percaya dengan menggunakan sistem teknologi informasi dapat bermanfaat dan dapat meningkatkan kinerja, maka pengguna akan menerima penggunaan sistem teknologi informasi. Sebaliknya, jika pengguna merasa sistem teknologi informasi kurang berguna, maka pengguna akan menolak penggunaan sistem teknologi informasi. Perceived ease of use sebagai kemudahan penggunaan sistem teknologi informasi yang dipersepsikan, meyakini bahwa pengguna akan lebih mudah memahami penggunaan sistem teknologi informasi tanpa harus menggunakan usaha yang keras dan terbebas dari kesulitan. Sedangkan attitude toward using merupakan perasaan seseorang 
baik positif maupun negatif apabila diharuskan melakukan perilaku tertentu (Davis, Marangunic, \& Granic, 2021). Attitude toward using dikonsepkan sebagai suatu sikap seseorang yang berbentuk penerimaan atau penolakan terhadap penggunaan suatu sistem tekologi guna untuk pemenuhan berbagai kegiatan dalam pekerjaannya (Widodo \& Azdy, 2017). Jika seseorang memiliki sikap positif terhadap information system technology, ia mendukung penggunaan dan kemudian mendorong penggunaan dan pemanfaatan teknologi sistem informasi.

Model TAM diadopsi dari Theory of Reasoned Action (TRA), yang pertama kali diperkenalkan oleh Martin Fishbein dan Ajzen tahun 1980. Teori ini menghubungkan antara keyakinan (believe), sikap (attitude), minat (intention) dan perilaku (behavior). Minat merupakan prediktor utama perilaku pengguna, artinya jika ingin mengetahui apa yang seseorang akan lakukan, yang terpenting adalah mengetahui minat orang tersebut. Meskipun seseorang dapat membuat keputusan berdasarkan alasan-alasan yang lain, artinya tidak selalu berdasarkan minat, namun konsep utama dalam teori ini adalah fokus untuk memperhatikan dan mempertimbangkan sesuatu yang dianggap penting oleh pengguna. Model TAM yang dikembangkan dari teori psikologis, menjelaskan bahwa perilaku pengguna teknologi informasi yaitu berdasarkan pada kepercayaan (believe), sikap (attitude), minat (intention), dan hubungan perilaku pengguna (user behaviour relationship). Model ini digunakan untuk menjelaskan faktor-faktor utama dari perilaku pengguna terhadap penerimaan (acceptance) teknologi informasi.

\section{METODE PELAKSANAAN}

\section{Jenis Penelitian}

Jenis penelitian yang digunakan adalah penelitian kausal, dimana tujuan penelitian ini untuk membuktikan hubungan antara sebab dan akibat dari beberapa variabel (Hermawan \& Amirullah, 2016). Dalam penelitian ini, hubungan sebab akibat antar variabel sudah diprediksi dan dikembangkan oleh peneliti. Sedangkan untuk jenis penelitian ini menggunakan pendekatan kuantitatif dengan metode cross-sectional, dimana peneliti menyebarkan kuesioner untuk mendapatkan jawaban dari responden dalam bentuk angka dengan menggunakan skala Likert pada suatu waktu.

\section{Populasi dan Sampel}

Populasi yang akan digunakan dalam penelitian ini adalah seluruh mahasiswa Universitas Ma Chung. Sedangkan untuk pengambilan sampel, peneliti menggunakan teknik 
Purposive Sampling atau Judgemental Sampling. Dalam teknik ini, sampel dipilih berdasarkan penilaian dari peneliti berdasarkan maksud dan tujuan penelitian, dimana sampel yang dipilih dapat mewakili populasi (Hermawan \& Amirullah, 2016).

Oleh karena itu peneliti menentukan sampel yang digunakan adalah mahasiswa S1 Program Studi Manajemen dan mahasiswa S2 Program Magister Manajemen Inovasi Universitas Ma Chung, yang diperkirakan akrab dengan penggunaan $e$-wallet dan memiliki probabilitas tinggi dalam mengisi kuesioner. Adapun jumlah respondennya adalah sebanyak 62 (enam puluh dua) orang responden. Pengumpulan data dilakukan dengan cara membagikan kuesioner.

\section{Pengukuran Variabel}

Di dalam sebuah penelitian diperlukan variabel untuk mengubah masalah yang diteliti ke dalam bentuk variabel, dan menentukan jenis dan indikator dari variabel-variabel dependen. Variabel yang digunakan dalam penelitian ini ada 2 (dua) jenis, yaitu variabel independen (x) dan variabel dependen (y). Berikut variabel-variabel yang digunakan dalam penelitian ini.

1. Variabel Independen

Atau disebut dengan variabel bebas merupakan variabel yang menjadi sebab perubahannya atau timbulnya variabel dependen (variabel terikat) - (Sugiyono, 2017). Dalam penelitian ini yang menjadi variabel independen adalah perceived usefulness (X1) dan perceived ease of use (X2). Pengukuran perceived usefulness menggunakan 8 (delapan) pertanyaan. Kedelapan pertanyaan diberikan kepada responden yang telah ditentukan agar dapat diketahui kebermanfaatan e-wallet yang dipersepsikan oleh pengguna. Sedangkan pengukuran perceived ease of use dilakukan dengan menggunakan 7 (tujuh) pertanyaan. Ketujuh pertanyaan diberikan kepada responden yang telah ditentukan, agar dapat diketahui kemudahaan $e$-wallet yang dipersepsikan oleh pengguna.

2. Variabel Dependen

Selain variabel independen, diperlukan juga variabel dependen atau biasa disebut variabel terikat yang merupakan variabel yang dipengaruhi atau yang menjadi akibat karena adanya variabel independen atau variabel bebas. Dalam penelitian ini variabel dependen-nya adalah attitude toward using (Y1). Pengukuran attitude toward using dilakukan dengan 
menggunakan 7 (tujuh) pertanyaan yang diberikan kepada responden yang telah ditentukan, agar dapat diketahui sikap responden terhadap e-wallet.

\section{Kerangka Penelitian}

Berikut ini merupakan gambar kerangka penelitian dengan menggunakan variabelvariabel yang akan dibahas dalam penelitian ini:

H1: Pengaruh perceived usefulness (X1) yang positif dan signifikan terhadap attitude toward using (Y1)

H2: Pengaruh Perceived ease of use (X2) yang positif dan signifikan terhadap attitude toward using (Y1)

\section{Gambar 1}

\section{Kerangka Penelitian}

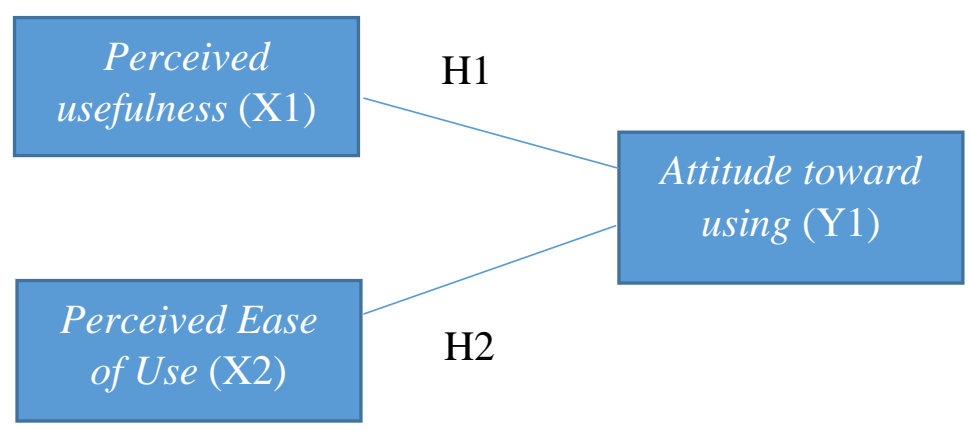

\section{Skala Pengukuran Variabel}

Di dalam penelitian ini, variabel diukur dengan menggunakan skala Likert. Skala ini dikembangkan oleh Rensis Likert. Skala likert digunakan secara luas yang mengharuskan responden untuk menunjukkan derajat setuju atau tidak setuju kepada setiap statement yang berkaitan dengan onjek yang dinilai (Hermawan \& Amirullah, 2016). Dalam penelitian ini, skala Likert digunakan untuk mengetahui pendapat mahasiswa aktif Universitas Ma Chung terhadap variabel penelitian yang terlah dirumuskan. Berikut merupakan pengukuran skala Likert.

Tabel 1

\section{Skala Likert}

\begin{tabular}{|c|c|c|}
\hline Kategori & Simbol & Nilai Bobot \\
\hline Sangat Setuju & SS & 5 \\
\hline Setuju & S & 4 \\
\hline Ragu-Ragu & R & 3 \\
\hline
\end{tabular}




\begin{tabular}{|c|c|c|}
\hline Tidak Setuju & TS & 2 \\
\hline Sangat Tidak Setuju & STS & 1 \\
\hline
\end{tabular}

\section{Uji Instrumen Penelitan}

Uji instumen penelitian bertujuan agar data yang digunakan dapat mewakili atau mencerminkan keadaan sesungguhnya. Berikut merupakan beberapa uji insturmen penelitian.

1. Uji Validitas

Uji Validitas menunjukkan sejauh mana kuesioner dapat mengukur variabel yang akan diukur. Dalam penelitian ini uji validitas menggunakan korelasi Pearson. Teknik uji validitas item dengan korelasi Pearson yaitu dengan cara mengkorelasikan skor item dengan skor totalnya. Item dapat dikatakan valid jika adanya korelasi yang signifikan dengan skor totalnya. Kemudian pengujian signifikansi dilakukan dengan kriteria menggunakan $r$ tabel pada tingkat signifikansi 0,05 dengan uji 2 sisi (Sig 2 tailed). Jika nilai positif dan $\mathrm{r}$ hitung $\geq \mathrm{r}$ tabel maka item dapat dinyatakan valid, jika $\mathrm{r}$ hitung $<\mathrm{r}$ tabel maka item dinyatakan tidak valid (Ghazali, 2018).

2. Uji Reliabilitas

Pengujian reliabilitas digunakan untuk mengetahui apakah alat ukur yang digunakan tetap konsisten hasilnya jika dilakukan pengukuran berulang. Pada penelitian ini digunakan metode Cronbach's Alpha. Dimana dari nilai koefisien Cronbach's Alpha dapat diketahui apakah suatu instrumen memiliki reliabilitas yang baik atau tidak. Jika koefisien Cronbach's Alpha lebih besar dari 0,70 maka dapat dikatakan bahwa suatu instrumen tersebut memiliki reliabilitas yang baik.

3. Uji Asumsi Klasik

Sebelum melakukan analisis data untuk mencari pengaruh antar variabel yang dipakai untuk penelitian, dilakukan uji asumsi yaitu uji normalitas residual, uji multikolinieritas dan uji heteroskedasitas.

a. Uji Normalitas Residual

Uji ini digunakan untuk mengetahui apakah sampel yang diambil dari populasi terdistribusi normal atau tidak. Hasil uji normalitas kemudian dibandingkan 
dengan nilai signifikansi, jika hasil nilai signifikansi lebih besar dari 0,05 (sig>0,05) dapat disimpulkan bahwa data penelitian terdistribusi normal (Ghazali, 2018).

\section{b. Uji Multikolinieritas}

Uji multikolinieritas digunakan untuk mengetahui besarnya interkolerasi antar variabel bebas dalam penelitian ini. Jika terjadi korelasi, maka diindikasikan terdapat permasalahan multikolinieritas. Hal tersebut dapat ditinjau dari nilai tolerance dan Variance Inflation Factor (VIF), indikatornya adalah jika nilai toleransi diatas 0,1 dan nilai VIF dibawah 10 maka tidak terjadi multikolinieritas (Ghazali, 2018).

\section{c. Uji Heteroskedastisitas}

Uji heteroskedastisitas digunakan untuk menguji apakah dalam model persamaan regresi terjadi ketidaksamaan varian. Model regresi yang baik indikatornya adalah tidak terjadi heteroskedastisitas. Pada penelitian ini digunakan diindikasikan bahwa model regresi pada penelitian tidak terjadi heteroskedastisitas (Adam, 2018). heteroskedastisitas dengan menggunakan uji Glejser. Indikator hasil 
uji Glejser adalah jika variabel bebas mempunyai nilai signifikasi lebih besar dari 0,05 dapat

\section{Uji Hipotesis}

Untuk mengetahui signifikasi dari hipotesis dalam penelitian ini maka perlu dilakukan beberapa uji, antara lain sebagai berikut:

\section{a. Uji Simultan}

Menurut (Ghazali, 2018) uji pengaruh simultan atau uji F digunakan untuk mempengaruhi apakah variabel independen bersama-sama atau simultan mempengaruhi variabel dependen.

\section{b. Uji Parsial}

Uji Parsial atau uji $\mathrm{t}$ digunakan untuk menguji pengaruh masing-masing variabel indepeden yang digunakan dalam penelitian ini terhadap variabel dependen secara parsial (Ghazali, 2018).

\section{HASIL DAN PEMBAHASAN}

Hipotesis pertama (H1) dalam penelitian ini adalah perceived usefulness berpengaruh positif terhadap attitude toward using. Perceived usefulness memiliki nilai signifikansi sebesar 0,143>0,050 (tidak signifikan) dengan nilai t hitung sebesar 1,485 (tidak ada pengaruh). Hal ini menunjukkan bahwa perceived usefulness tidak berpengaruh terhadap attitude toward using mahasiswa dalam menggunakan $e$-wallet pada masa pandemi Covid-19 sehingga H1 ditolak. Hasil penelitian ini sesuai dengan penelitian Tyas \& Darma (2017). Tetapi, hasil penelitian ini tidak sesuai dengan penelitian oleh Komalasari \& Marjito (2019), Bangkara \& Mimba (2016), Setyawati (2020), dan Sandi et.al (2021) yang menyebutkan bahwa perceived usefulness berpengaruh positif terhadap attitude toward using.

Peneliti menduga hal ini terjadi karena mahasiswa telah menggunakan e-wallet dalam jangka waktu yang lama. Pada penelitian ini, banyak sampel yang telah menggunakan $e$-wallet selama lebih dari 1 (satu) tahun, dengan intensitas lebih dari 5 kali dalam sebulan. Semakin tinggi intensitas penggunaan $e$-wallet, maka kebermanfaatan yang dirasakan akan semakin menurun. Hal ini bisa juga disebabkan karena provider $e$-wallet jarang melakukan pembaruan fitur. 
Peneliti menduga juga bahwa kebermanfaatan $e$-wallet belum secara signifikan dirasakan mahasiwa yang berkaitan dengan kegiatan transaksi. Belum terasanya kebermanfaatan oleh mahasiswa terlihat dari jawaban kuesioner yang banyak memilih skor 3 (tiga). Hal ini menunjukkan bahwa mahasiswa ragu-ragu terhadap kebermanfaatan $e$ wallet. Adapun penyebabnya adalah mahasiswa masih memiliki kebiasaan menggunakan uang tunai dalam bertransaksi. Selain itu banyak merchant yang belum menerima sistem pembayaran dengan menggunakan $e$-wallet.

Hipotesis kedua $(\mathrm{H} 2)$ dalam penelitian ini adalah perceived ease of use berpengaruh positif terhadap attitude toward using. Perceived ease of use memiliki nilai signifikansi sebesar 0,002 < 0,050 (signifikan) dengan nilai t hitung sebesar 3,249 (positif). Hal ini menunjukkan bahwa perceived ease of use berpengaruh positif terhadap attitude toward using terhadap e-wallet pada masa pandemi Covid-19, sehingga H2 diterima. Hasil penelitian ini sesuai dengan penelitian Komalasari \& Marjito (2019), Bangkara \& Mimba (2016), Setyawati (2020). Tetapi, hasil penelitian ini tidak sesuai dengan penelitian Tyas \& Darma (2017), Perangin-angin et.al. (2016), dan Sandi et.al. (2021) yang menyebutkan bahwa perceived ease of use tidak berpengaruh terhadap attitude toward using.

Setiap orang mengeluarkan tingkat usaha yang berbeda-beda dalam penggunaan $e$ wallet. Ketika $e$-wallet mudah digunakan, pengguna tidak memerlukan tenaga dan waktu yang banyak untuk mempelajari, memahami, dan menggunakan $e$-wallet tersebut. Ada beberapa kemudahan yang ditawarkan oleh $e$-wallet, salah satunya adalah bisa dilakukan di mana saja dan kapan saja. Persepsi kemudahan dari $e$-wallet dapat diwujudkan dengan syarat para pengguna e-wallet menerima sistem yang ada dan menaruh kepercayaan bahwa $e$-wallet memudahkan melakukan transaksi. Kemudahan penggunaan $e$-wallet juga dirasakan oleh kalangan mahasiswa.

\section{KESIMPULAN}

Dalam penelitian ini menunjukkan bahwa perceived usefulness tidak berpengaruh terhadap attitude toward using mahasiswa dalam menggunakan $e$-wallet pada masa pandemi Covid-19. Hal ini dikarenakan mahasiswa telah menggunakan $e$-wallet dalam jangka waktu yang lama, sehingga kebermanfaatan yang dirasakan akan semakin menurun. Hal ini juga dapat disebabkan karena pengembang $e$-wallet jarang melakukan pembaruan fitur.

Adapun perceived ease of use berpengaruh positif terhadap attitude toward using terhadap e-wallet pada masa pandemi Covid-19. Hal ini karena ada beberapa kemudahan 
yang ditawarkan oleh $e$-wallet, dan mahasiswa menerima sistem yang ada dan menaruh kepercayaan bahwa $e$-wallet memudahkan melakukan transaksi.

Untuk penelitian selanjutnya maka disarankan untuk menambah jumlah sampel dan jumlah variabel pengukuran yang digunakan. Selain itu peneliti menyarankan kepada $e$ wallet provider untuk lebih sering memperbaharui fitur yang memudahkan pengguna. Hal tersebut bertujuan untuk menarik minat banyak orang untuk menjadi pengguna $e$-wallet.

\section{DAFTAR PUSTAKA}

Adam, M. (2018). Practical Guide of the Integrated Structural Equation Modeling (SEM) with LISREL and AMOS for Marketing \& Social Sciences Thesis. Yogyakarta: Deepublish.

Arikunto, S. (2006). Prosedur Penelitian Suatu Pendekatan Praktik. Jakarta: Rineka Cipta. Bangkara, R. P., \& Mimba, N. P. S. H. (2016). Pengaruh Perceived Usefulness dan Perceived Ease of Use Pada Minat Penggunaan Internet Banking dengan Attitude Toward Using Sebagai Variabel Intervening. E-Jurnal Akuntansi Universitas Udayana, Vol.16 No. 3, pp. 2408-2434.

Davis, F.D., Marangunic, A., \& Granic, A. (2021). The Technology Acceptance Model - 30 Years of TAM. New York: Springer International Publishing

Hermawan, S., \& Amirullah. (2016). Metode Penelitian Bisnis Pendekatan Kuantitatif dan Kualitatif. Malang: Media Nusa Creative.

Eloksari, E. A. (2020, March 20). Retrieved from https://www.thejakartapost.com/: https://www.thejakartapost.com/news/2020/03/20/food-deliveries-online-gamepurchases-up-as-people-stay-at-home-during-covid-19-pandemic.html

Ghazali, I. (2018). Aplikasi Analisis Multivariate Dengan Program IBM SPSS 25. Semarang: Badan Penerbit Universitas Diponegoro.

http://hukor.kemkes.go.id. (2020, June 19). Retrieved from http://hukor.kemkes.go.id/uploads/produk_hukum/KMK_No_HK_01_07MENKES-382-

2020_ttg_Protokol_Kesehatan_Bagi_Masyarakat_di_Tempat_dan_Fasilitas_Umum _Dalam_Rangka_Pencegahan_COVID-19.pdf

Komalasari, Y., \& Marjito. (2019). Pengaruh Perceived Ease of Use dan Perceived Usefulness Terhadap Attitude Toward Using Pada Ojek Online Uber. Jurnal Computech \& Bisnis, Vol. 13 No. 1, pp. 11-17.

Lestari, R. (2020, Oktober 13). Retrieved from www.kabar24.bisnis.com: https://kabar24.bisnis.com/read/20201013/19/1304375/survei-unctad-pandemimengubah-tren-belanja-online

Pendidikan2, D. (2021, May 15). www.dosenpendidikan.id. Retrieved from https://www.dosenpendidikan.co.id/e-money-adalah/\#Sejarah_Kelahiran_EMoney_di_Dunia

Perangin-angin, W. A., Respati, A. D., \& Kusumawati, M.D. (2016). Pengaruh Perceived Usefulness dan Perceived Ease of Use terhadap Attitude Toward Using E-Faktur. Journal of Research in Economics and Management., Vol. 16 No. 2, pp. 307-322.

Prasetyo, W. B. (2021, Maret 29). https://www. beritasatu.com. Retrieved from https://www.beritasatu.com/ekonomi/752563/transaksi-uang-elektronik-gunakandompet-digital-meningkat

Ridhoi, M. A. (2020, Oktober 29). katadata.co.id. Retrieved from https://katadata.co.id/muhammadridhoi/analisisdata/5f97c41b49705/mana-yangpaling-favorit-e-money-atau-e-wallet 
Sandi, A. S., Soedijono, B., \& Nasiri, A. (2021). Pengaruh Kegunaan dan Kemudahan Terhadap Sikap Penggunaan Dengan Metode TAM Pada Sistem Informasi Magang. IT Journal Research and Development (ITJRD), Vol. 5, No. 2, pp. 109117.

Setyawati, R. E. (2020). Pengaruh Perceived Usefulness, Perceived Ease of Use Terhadap Behavioral Intention to Use Dengan Attitude Towards Using Sebagai Variabel Intervening. Jurnal Ekobis Dewantara Vol. 3 No. 1, pp. 39-51.

Sugiyono. (2017). Metode Penelitian Kuantitatif, Kualitatif, dan R\&D. Bandung: Alfabeta, $\mathrm{CV}$.

Tyas, E. I. \& Darma, E. S. (2017). Pengaruh Perceived Usefulness, Perceived Ease of Use, Perceived Enjoyment, dan Actual Usage Terhadap Penerimaan Teknologi Informasi: Studi Empiris Pada Karyawan Bagian Akuntansi dan Keuangan Baitul Maal Wa Tamwil Wilayah Daerah Istimewa Yogyakarta dan Sekitarnya. Reviu Akuntansi dan Bisnis Indonesia, Vol. 1 No. 1, Hlm: 25-35, Juli 2017.

Undang-Undang RI No.8 Tahun 1999 pasal (1) ayat (2) tentang Perlindungan Konsumen Wikipedia. (2021, May 17). Retrieved from id.wikipedia.org:

https://id.wikipedia.org/wiki/Dompet_elektronik

www.bi.go.id. (2020). Retrieved from www.bi.go.id: https://www.bi.go.id/QRIS/default.aspx

www.bi.go.id. (2021). Retrieved from https://www.bi.go.id/id/statistik/ekonomikeuangan/ssp/uang-elektronik-jumlah.aspx

(C) 2021 by authors. Content on this article is licensed under a Creative Commons Attribution 4.0 International license. (http://creativecommons.org/licenses/by/4.0/). 